\title{
Riau Malay food culture in Pekanbaru, Riau Indonesia: commodification, authenticity, and sustainability in a global business era
}

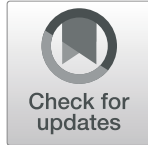

\author{
Annisa Mardatillahº, Sam'un Jaja Raharja, Bambang Hermanto and Tety Herawaty
}

\begin{abstract}
The purpose of this research is to provide an in-depth analysis of the commodification, authenticity, and sustainability of culinary legacy as an instance of intangible cultural legacy, as well as how to subsequently compete with excellence and sustainability in the midst of a modern, global era of business without the loss of authenticity value. Herein is revealed the application of true local culture amid commercialization and modernization, differentiating between the authenticity and that which is out-of-sorts with local identity. The controversy of contextualization, the discussion of what is necessary, and the commodification of traditional food, namely the traditional foods of Riau Malay, to respond to the demand of a global market, are areas of interest in this study, as well as how the traditional foods of Riau Malay may compete with excellence and sustainability in a global market while retaining its authenticity values. The methodology used in this research is qualitative phenomenological; the interviews were carried out from the informants who were cultural figures of Riau Malay, social figures, and business actors in the traditional Riau Malay food industry with resulting evidence that confirms the necessity of heritage value of traditional Riau Malay foods, commodification in the area of globalization, without necessitating any loss of authenticity elements. The cultural heritage of traditional Riau Malay foods is introduced in two different types, cake pastry and main course savory dishes, and divided into two categories, everyday cuisine and cuisine for ceremonies or rituals. Riau Malay natives have customs and culture involved in the preparation and processing; presentation and consumption of the food may also be seen in the efforts in preparing such a traditional menu. The findings of this study are expected to contribute to the literature and research interest in food culture.
\end{abstract}

Keywords: Traditional Riau Malay food, Food culture, Commodification, Heritage value, Sustainability, Globalization

\section{Introduction}

Research into the commodification, authenticity, and sustainability of cultural culinary legacy in the global market era is currently quite the object of interest for research potential. An interesting debate exists examining the commodification of the legacy of traditional cuisine in the global business era. Commodification constitutes a process interconnected with capitalism consisting of an object becoming a commodity and market product [1]. Food is a market product that also undergoes a mobilization process along with the commodification in the global business era and results in new business opportunities [2]. However, those who resist globalization consider this process of commodification to be, on the contrary, an instance of hegemony and cultural imperialism [3], a

\footnotetext{
* Correspondence: annisa17050@mail.unpad.ac.id
}

Universitas Padjadjaran, Bandung, Indonesia
"McDonaldization" [4] that may lead to homogenization and a resulting "global palate."

Cuisine constitutes an intangible cultural inheritance symbolizing cultural identity passed down from generation to generation, and its existence is a measure of the richness of the culture of a community $[5,6]$. However, this sacred cultural value has now become a commodity of trade as a result of the commodification in the global market era [7, 8]. Cuisine carries the function of creating sustainable history and uniting a culture, due to its sense of shared ownership [9], to the extent that cultural commodification leads to pride and an awareness of one's authenticity culture [8].

People's cultural values may be seen in the variety and complexity of their cultural arts and in every aspect of their lives. Traditional cuisine constitutes an intangible cultural inheritance that is a fruit of society's labor in a

(c) The Author(s). 2019 Open Access This article is distributed under the terms of the Creative Commons Attribution 4.0 International License (http://creativecommons.org/licenses/by/4.0/), which permits unrestricted use, distribution, and 
given era, building on traditional knowledge proceeding from intimate experience with utilizing the natural resources that are available, in the comprehensive human pursuit of survival [10].

Culinary heritage is considered a global asset and a local resource providing opportunity to build up historical narrative in social, environmental, economical, and political aspects [11]. Matta [12] states that culinary heritage is a shared ownership inheritance composed of a combination of material and immaterial elements of the said culture. These include dining etiquette, symbolic dimensions of food, material ingredients, and the arrangement of dining equipment such as tables, dishes, and the like [13].

Traditional food is a food product that, according to gastronomy, does not undergo a manipulated process [9], and having been passed down from a previous era, is in use up until the current time [14]. Traditional food is considered to have relatively high intrinsic quality due to its historical element [15]. It is traditional food that carries a trademark quality of eliciting strong emotion, experience, and sensation in the midst of the people in question, such that individuals are united in shared feeling to a collective experience joined with that of the past [16].

Almost four decades prior, researchers declared that choice of food tends to be an indicator of social relationships [17]; a symbol of social caste, class, and hierarchy [18]; and a metaphor of building up the ethnicity and identity of a given culture [19].

Furthermore, based on [20], food also functions as a marker of the identity of individuals and groups of people, because food can communicate classes, community, ethnic groups, lifestyle, and other social classes. Social class groups, ethnic groups, and lifestyles determine the choice of food they consume. Therefore, food choices in individuals and groups can create eating habits.

Similar to previous studies, Kittler et al. [21] shown that the habit of determining food choices is also known as a food culture that describes the way humans determine food choices, starting from how food is chosen, obtained, prepared, served, and eaten. Food culture is the food choices that are also determined by the complexity of personal, economic, religious and ethnicity finally reflects values and habits [22]. Furthermore, Tarr [22] emphasizes that the process of food culture is not only a small part of the culture but is a whole form of the food culture itself.

In the modern global era, people's lives have come to be shaped not only by the conditions of the immediate local environment, but more and more by the modern world. Globalization brings forth the conflict between local and global environments and may result in the creation of either homogeneity or heterogeneity [23].

Globalization of food products influences the actions of people in affecting their choice of food for consumption and triggers commodification. According to [24], global values are part of a process leading to the disappearance of local values. Whereas [25] argues that globalization constitutes an opportunity to reaffirm local cultural identity in order to be better known in the multifaceted world, the draw of the strength of local culture now being of greater importance amid the monotonous homogeneity of society's life due to globalization. Local values can inspire local culture, which emerge from life values, which in turn give meaning to life.

Therefore, Kwon [26] emphasized, currently, the global community in deciding on the food choices they consume which is interesting in choosing food products that based on history, cultural, and geographical features so the meaning of these choices is shown that they do not just eat the food products but also they learn about the culture, history, and geography contained in these foods of each country around the world.

The dissatisfaction of society with the homogeneity of globalization gives strength to traditional cuisine being seen as holding significant economic benefit with the potential to become a unique and expensive commodity [11]. The rise in interest in traditional cuisine has spread to all business sectors, to producers and to consumers, both industrial as well as retail sectors [5, 26-28].

From the consumers' perspective, interest in food choices is seen as emerging from social change in the era of globalization and the increase in the industrialization of the food sector [5]. Valuing a plethora of traditional foods is one way we can preserve them from extinction, and at the same time, commercialization of traditional food in the direction of modernization has discredited the perspective of the preservationist [29].

According to the UNESCO 2003 Convention for the Protection of Intangible Cultural Heritage, intangible cultural heritage is defined as follows:

The practices, representations, expressions, knowledge, skills-as well as the instruments, objects, artefact and cultural spaces associated there with p that communities, groups and, in somes cases, individuals recognize as part of their cultural heritage. This intangible cultural heritage, transmitted from generation, is constantly recreated by communities and groups in response to their environment, their interaction with nature and their history, and provides them with a sense of identity and continuity, thus promoting respect for cultural diversivity and human creativity (UNESCO, 2003).

Currently, the issue of the commodification of traditional food heading toward commercialization and modernization, in the case of Riau Malay, in this era of globalization, has become a serious issue, not only among traditional Riau Malay society, but also in the business 
sector. The dilemma between the paradox of preserving authenticity cultural identity and values carried in the culinary heritage, and the demands of commodification in the global market, causes identity confusion to arise, which eventually leads to the loss of tradition and identity. Change in market interests causes the actors in the Riau Malay traditional food business to engage in commodification in various aspects, such as varying food flavors and preparation methods.

In this article, the researchers explore the commodification of the culture of Riau Malay traditional food in terms of historical value (HV) [9, 30-34], the commodification of culinary heritage as an intangible cultural heritage, and how to be able to compete with excellence and sustainability amid the modernization of the global business era, needing not only to survive in the competition of the global market, but also to retain the authenticity identity of the Riau Malay traditional food itself. This is seen in the cultural practice of a decision-making process identifying authentic foods and those which are not in accordance with true local identity. Next, the question is whether in the context of traditional Riau Malay food commodification is necessary to respond to the demands of a global market. Given these questions, this research is of great interest, since among previous works of research, none focus on the commodification and sustainability of traditional Riau Malay food in the global business era in connection with the questions raised by previous researchers. Although it is evident that identifying the dimensions of a cultural heritage is a challenging task, necessitating memory, tradition, identity, change, and behavior, to raise up a local culture to become a premium product valued outside its place of origin [11], nevertheless, at its core, the confusion between guarding tradition and the commodification of cultural tradition needs to be investigated more seriously, so that the traditional food of Riau Malay will be able to compete in the modern world without losing its identity and authenticity, but rather strengthen its identity and authenticity in the global market for the sake of sustainable excellence.

\section{Materials and methods}

This study uses a phenomenological approach. The choice of this approach is designed to better describe concepts or phenomena; by the way, people involved in these phenomena explore human life experiences to find the essence of the meaning of that experience [35]. The sampling technique used was purposive sampling, with the aim of the research. Representative research subjects were selected based on available information and data. Data collection is done through observation, in-depth interviews, documentation, and focus group discussions (FGD). Observations were carried out with the aim of creating an original description of the field conditions in the cultural heritage of traditional Malay Riau food. We make observations on the kinds of traditional Riau Malay foods, starting from history, how to cook, ingredients, original taste, and commodification. Interviews and FGDs were conducted with a number of informants to get a comprehensive picture of their perceptions, responses, and attitudes toward the commodification and sustainability of traditional food cultural heritage.

Informants were figures from Riau Malay culture, social figures and business people in the Riau Malay traditional food industry. We asked the leaders of Riau Malay culture about the history and philosophy of traditional Malay Riau food, cooking methods according to the legacy of the past, the taste of authenticity of food, also reviewing a scientific paper and literature of traditional Riau Malay Food. The pictures in this were taken from some literature. Our data analysis method follows [36] as a model of interactive and comparative analysis, compared to previous research work.

\section{Result and discussion Understanding heritage values in the food culture of traditional Riau Malay food}

Over the past decade, it has been known from previous studies on food culture both from a food perspective is an identity culture and company emphasizing food culture as an advantage for sustainability in global competition. Liu et al. [37] emphasized that food culture is a technology, a science where there is art in the development and processing of food ingredients including production and consumption activities, besides that there are habits and traditions as thoughts born on a diet consisting of a combination of process and food production functions.

Meanwhile, previous studies of management company focus emphasized food culture as the uniqueness of the value of cultural diversity of authenticity as a strength for companies to gain a market competition [36, 37]. Furthermore, Wang [38] emphasized that food culture is an accumulation of local culture as authenticity from cultural heritage. In addition, [39] shown culture as human intellectual thinking originating from the legacy of the previous generation and can be passed on to the next generation.

Based on previous research, this study emphasizes the heritage value of authenticity as a food culture which is a unique habit for human life that has differences in each region. In the context of Malay food culture in Riau, there is a habitual way of being called food culture in processing and eating food, cultural heritage obtained from the past cultural heritage as heritage value from generation to generation.

However, food culture is from the habit of humans being prepared how to eat their food into a culture of 
regional identity that is formed from the process of beliefs, values, norms, and social classes that identify culture as part of the human self itself. For indigenous Malay Riau people, food creates a Malay cultural identity where they believe that a distinctive taste will reflect the cultural identity of a strong Riau Malay community.

We believe that the type of food chosen for person's meal reflects their identity. Similar to [21] which emphasizes that food serves as an important symbol of identity culture, in addition [21] to the appropriate food choices in people's habits of each cultural community often related to religious beliefs or ethnic behavior, it signifies cultural identity affirmation related to food choices which also signifies collective association as a combination of cultural identity beyond self-identification. For example, Riau Malay people do not eat pork or pork oil content in their food and there is no mixture of alcohol or the like because they are related to the Islamic religion that they believe prohibits them from consuming these foods. Halal food according to Islamic religious beliefs is a mandatory choice that is prioritized in daily consumption.

Furthermore, food culture in eating the main course affirms the cultural identity of Malay Riau. Makan Beridang is sitting in a row together on the floor with long clothes like sheets. Food is arranged on a round tray. Rounded shapes symbolize that there is no rectangular angle which is believed to hinder togetherness. The meaning of the value of simplicity and togetherness maintains harmony between people.

In addition to the Malay food culture, it is inseparable from Islamic religious law, wherein in one tray, the meal must contain 5 adults or 7 children, to always remember the five pillars of Islam. Serving begins with serving water and rice, and the plate is then covered with a dish. In addition, Riau Malay food must prioritize Halal as value contained in Islamic Sharia. Riau Malay food does not use preservatives or chemical food coloring because Riau Malay people believe that choosing healthy foods generates a healthy body and soul.

Cultural identity in the current era of globalization has become a dilemma that is considered from the story of past history while globalization is often associated with changes in the environment that dynamically talk about homogeneity. Homogeneity is a process of equality between local cultures that contain cultural identity with modern culture. This homogeneity is feared to eliminate the identity of the local culture as a source of unique distinguishing strengths from various ethnic backgrounds. It similarly appeared in the context of food selection that reflects the cultural identity of a community group.

Regarding the context of the current situation of traditional Riau Malay food, it currently appears to be in a state of dilemma, between protecting tradition and allowing commodification of tradition to develop freely. The presence of modern foods as a result of modernization proffers its own allure as a local business opportunity for those who would align with it via the commercialization of traditional food in the direction of modernization. This phenomenon is seen in various changes which are made from the standard authenticity ingredients used, the authenticity traditions involved, and the cooking methods employed.

The nature of the native Riau Malay society is to strongly value and preserve local culture, including the values associated with traditional Riau Malay food, depicted in everyday customs and behavior, from the choice of ingredients, the preparation of food, and the presentation of it, culminating in the unique trademark sense-and-feel of the food that carries that authenticity Riau Malay identity, from the first bite to the last.

Based on the results of interviews with figures from Riau Malay culture that the appreciation Riau Malay natives have for the customs and culture involved in the preparation and processing, presentation and consumption of the food may also be seen in the efforts of a woman in preparing such a traditional menu. The process of cleaning and cutting fish for a traditional Riau Malay menu done correctly, such as the fish is cut in slant and a straight cut does not conform to custom, signifies contempt for the consumer. The following is one of the quotations from the interviews:

\section{Each type of food has a very traditional way of processing and serving. Traditional Riau Malay dishes may be divided into two categories: everyday cuisine, and cuisine for ceremonies or rituals. Each type has a differents traditional cooking styles.}

Based on the results of interviews, related to food culture in Riau Malay food, it can be seen that Riau Malay individuals and groups have a habit of choosing their food, including processing, obtaining, serving, and consuming. This food culture emphasized from generation to generation as a cultural heritage of Riau Malay food.

The traditional cooking styles of Riau Malay include roasting, smoking, sun-drying, cooking in underground ovens, boiling, steaming, frying, and wrapping fruit for accelerated ripening. From a historical perspective, roasting is identified as the oldest cooking process, involving simply the placing of food in or near coals. As for the methods of preservation, smoking over fires is identified as the most ancient process of enabling food to last longer. Cooking in underground ovens is another method traditionally employed by the Riau Malay, especially in cooking bananas, tubers, cereals, and even fish. It involves covering food with soil and ashes and then lighting a fire on top. Cooking in this manner takes $1.5 \mathrm{~h}$ for a full bake. Some examples of traditional Riau Malay food are 
introduced in two different types, cake pastry and main course savory dishes, and divided into two categories, everyday cuisine, and cuisine for ceremonies or rituals.

Categories of cake pastries are as follows: Kue Bangkit ("rising pastry"): this dry pastry is made from tapioca flour, eggs, sugar, and coconut milk. Authentically consumed by kings and nobility, it has become an integral part of traditional festivals and religious holidays. It is called kue bangkit ("rising pastry") because it rises to twice its size during the baking process. It is now being mass-produced as an everyday food in a variety of flavors and shapes. Bolu Kemojo ("Kemojo sponge cake"): the kemojo sponge cake is made of wheat flour, eggs, and sugar. The amount of sugar used serves as a natural preservative. It is named kemojo because its shape looks like the kemoja flower. This cake authentically had only one flavor, the essence of pandan. Now, it has undergone commodification and comes in many flavors. It is usually featured at traditional events such as weddings and religious holidays. Kue Asidah ("Asidah pastry"): the asidah pastry is made of wheat flour, eggs, cloves, cinnamon, and fried onions. It is usually present at traditional events such as weddings and religious holidays. Lempuk Durian: this dish is made just of durian and sugar. The flesh of a ripe durian fruit is stirred with white sugar until it forms a thick, uniform mixture. The high sugar content serves as a natural preservative. It is wrapped with areca leaves. Kue Jala Kinca Durian ("durian-sauce net pastry"): this pastry is made from wheat flour and eggs and is served in a durian sauce cooked with coconut milk and palm sugar. It is called a "net pastry" because it is formed full holes like netting. Bolu Berendam ("soaked sponge cake"): this trademark Riau snack is no ordinary sponge cake, as it is made from just a little flour, a lot of eggs, and sugar and served wet, in a sweet sauce made with cloves, cinnamon, and fennel. It has been served in Riau regularly dating back to the era of the Indragiri Hulu kingdom. Some of the pastries may be seen in Fig. 1.

Categories of main course savory dishes are as follows: Asam Pedas Ikan ("spicy-sour fish"): this dish is made of a trademark combination of spices such as onion, garlic, ginger, turmeric, and chili peppers, resulting in a unique sour and spicy flavor. The fish typically used are pangasius or mystus catfish native to the waters of Riau Malay. Ikan Selais Asap ("smoked fish"): Ikan selais asap is smoked for longevity without the need of preservatives. It is usually served with a chili pepper paste or made into a kind of curry along with cassava greens. Mie Sagu ("sago noodles"): this dish is made of sago flour shaped into noodles. They are cooked with a mixture of spices and may be boiled or fried. Nasi Lemak Pekanbaru: this rice dish is cooked with coconut milk and seasoning. It is served along with side dishes such as chicken, eggs, chili peppers, and vegetables. Some of the names of the main course savory dishes can be seen in Fig. 2 .

The concept of culinary heritage as an intangible heritage calls for attentiveness to the roles of individuals in committing to guarding the values inherent therein for the preservation of the aforementioned culinary heritage [29]. Culinary heritage serves as a symbol of cultural identity expressing the heart of people. For the people of Riau Malay, their heart is seen in the values passed down from generation to generation, which have taken root in a people, a tribe, forming a standard, an example that has been followed in generations past and will continue to be followed for generations to come [43].

\section{The authenticity and commodification of traditional Riau Malay food}

The authenticity of ethnic food is a legacy of regional wealth has a difference from each region. Understanding the definition of ethnic food, referring to [44] is an ethnic food derived from the ability of local knowledge in processing local resources such as raw materials for basic ingredients of food ingredients through plants and animal sources into an ethnic food accepted by consumers outside ethnic groups.

The use of authenticity was generally replaced by the originality of food culture [45]. Abarca [45] believed authenticity to impose an attitude on authentic culinary that inhibits creativity to make another version. Meanwhile, ethnic food is associated with local knowledge in the process of using local resources as a raw material for food. We believe that when local knowledge is no longer important on the processing of ethnic food, this will eliminate the authenticity of the ethnic food.

In the context of Riau Malay food, it is known that the authenticity of Riau Malay food comes from the composition of basic ingredients that thrive and come from the land and natural of Riau. Sago, tapioca flour, durian, fish sources, which are patin fish and selais fish, are the main source of staple foods which are ethnic foods in Riau Malay, as well as spices and pandan leaves that often become natural coloring in the Malay ethnic food of Riau.

Nowadays, ethnic food is not just talking about how to prepare, cook, serve, and preserve which concerns the culture and past history even though ethnic food cannot be separated from legacy, culture, ecology, and environment because modernization requires other meanings such as related matters about modesty in the manner of eating $[44,45]$.

Each region provides different local materials according to geographical conditions. As in Riau Malay food, the source of local raw materials for Riau's Malay ethnic food can not only be obtained from local geographic sources and while also provided from outside the geographical area of Riau Malay in general. However, local 


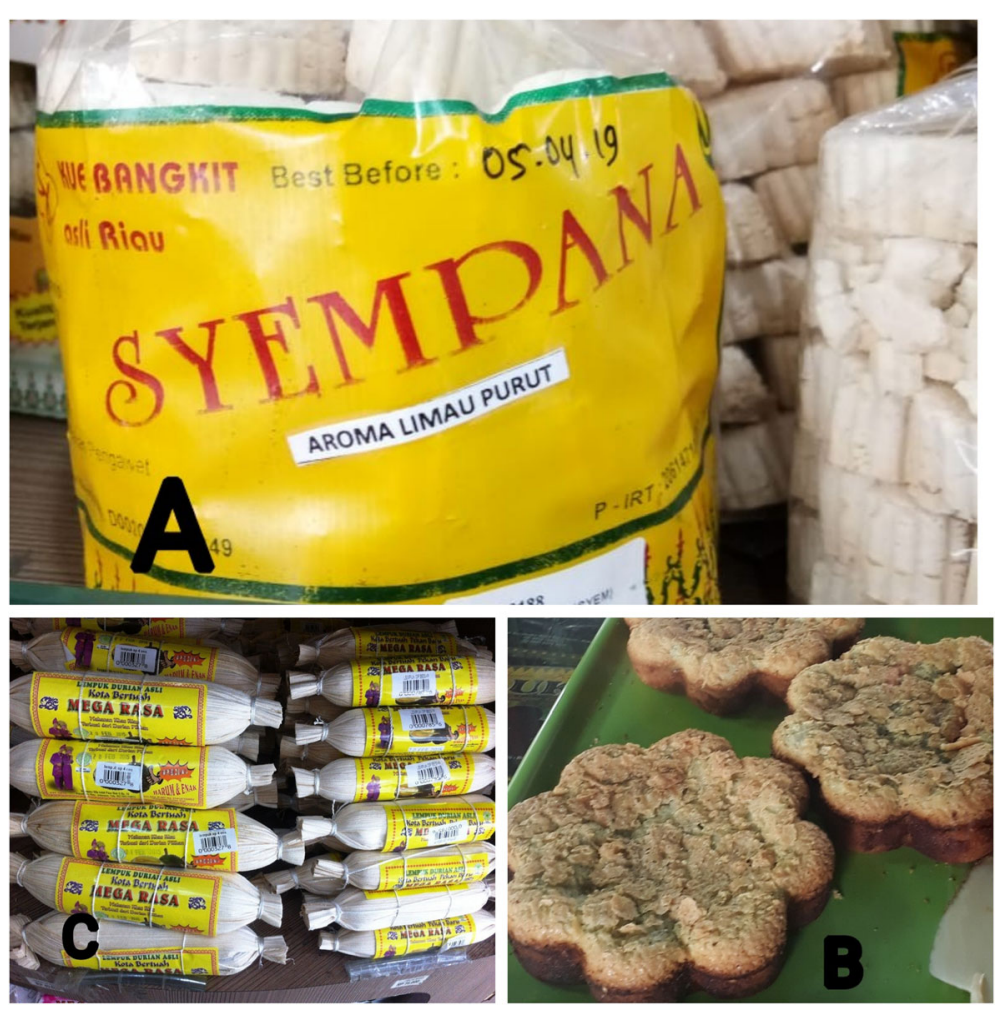

Fig. 1 Name of food (pastries). a Kue Bangkit ("rising pastry"): this dry pastry is made from tapioca flour, eggs, sugar, and coconut milk. Authentically consumed by kings and nobility, it has become an integral part of traditional festivals and religious holidays. It is called kue bangkit ("rising pastry") because it rises to twice its size during the baking process. It is now being mass-produced as an everyday food in a variety of flavors and shapes. $\mathbf{b}$ Bolu Kemojo ("Kemojo sponge cake"): the kemojo sponge cake is made of wheat flour, eggs, and sugar. The amount of sugar used serves as a natural preservative. It is named kemojo because its shape looks like the kemoja flower. This cake authentically had only one flavor, the essence of pandan. Now, it has undergone commodification and comes in many flavors. It is usually featured at traditional events such as weddings and religious holidays. c Lempuk Durian: This dish is made just of durian and sugar. The flesh of a ripe durian fruit is stirred with white sugar until it forms a thick, uniform mixture. The high sugar content serves as a natural preservative. It is wrapped with areca leaves

knowledge in the process of processing and presentation ethnic foods of Riau Malay as a strength of heritage value of authenticity comes from past history handed down from generation to generation.

Ethnic food has a unique identity including Riau Malay food and has an appeal that assimilates to culture through past experience. Currently, consuming ethnic food is not just to preserve it but to provide and reinforce happiness to past memories that effectively increase emotional effective [46]. Even today, some ethnic food leads to a commodity product that continues to develop in the food industry because of diverse ethnicity. According to [26, 44], food industry developing gradually which believed that ethnic food provides diverse ethnicity became a potential good to develop in food industry to sustain in gain markets globally. Failures in sustained competitive advantage came as the food industry failed to bring changes to the pattern of ethnic food production and consumption which eliminated the originality of heritage value as a cultural identity.

Under current conditions, traditional Riau Malay food is undergoing commodification as it seeks its place in the world of diverse foods in the global era. Over a century ago, the tradition of culinary selection was still based on social stratification indicators. From this historical value, types of traditional foods emerged in the context of kingdoms, which maintained the custom of presenting these foods at certain ceremonial celebrations for centuries. This practice came about in light of the basic stratification of Riau Malay society into two social classes: the common people, the governing class, and the nobility, a class of sultans. This setting carried consequences for the everyday lives of society, including in the choice of foods. The higher the social class, the greater the privilege, and the more choice in culinary selection. Today, however, traditional Riau Malay food is undergoing a transformation. The transformation of traditional Riau Malay food is being brought about by the commodification of the global era as necessary as part of survival by adaptation to market interests while fighting forces of modernization and commercialization that could lead to the disappearance of such food.

The era of globalization has entered the scene rapidly, bringing a great change in every aspect and realm of life. 

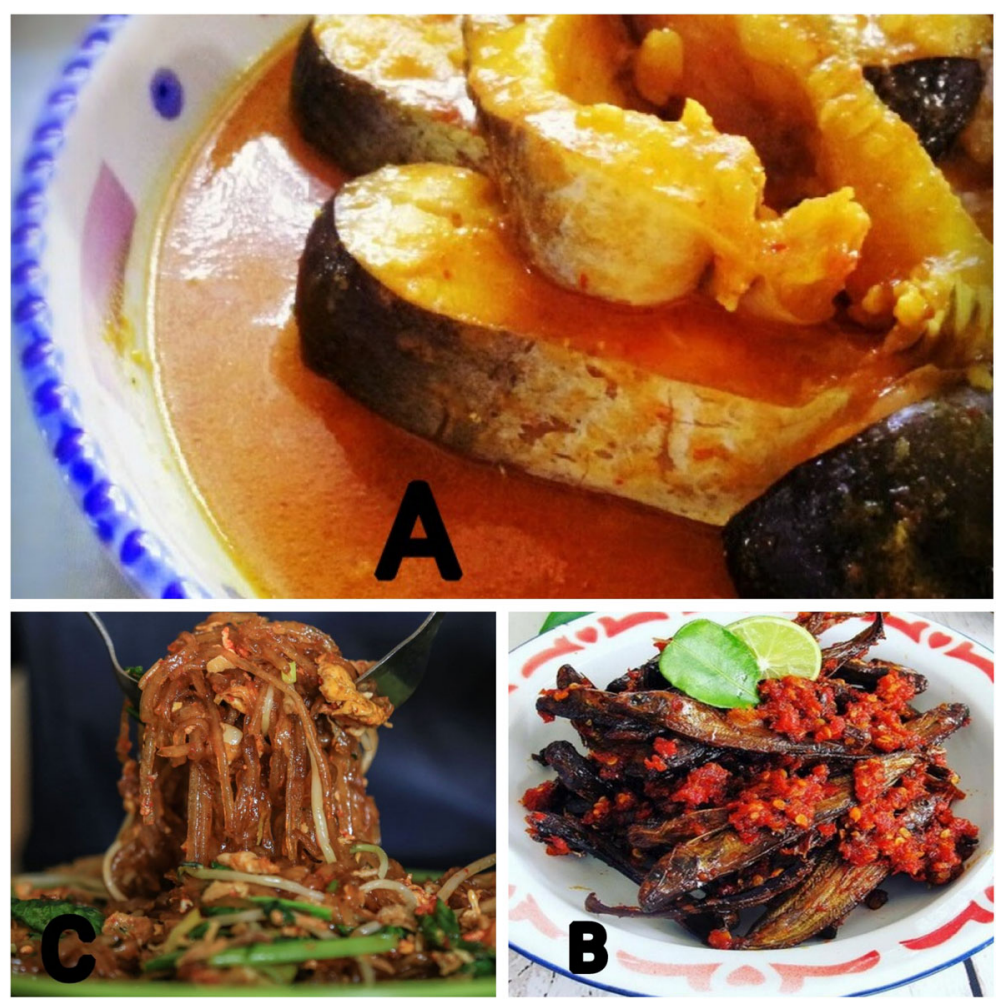

Fig. 2 Name of food (savory dishes) a Asam Pedas Ikan ("spicy-sour fish"): this dish is made of a trademark combination of spices such as onion, garlic, ginger, turmeric, and chili peppers, resulting in a unique sour and spicy flavor. The fish typically used are pangasius or mystus catfish native to the waters of Riau Malay [40]. b Ikan Selais Asap ("smoked fish"): Ikan selas asap is smoked for longevity without the need of preservatives [41]. It is usually served with a chili pepper paste or made into a kind of curry along with cassava greens. c Mie Sagu ("sago noodles"): this dish is made of sago flour shaped into noodles. They are cooked with a mixture of spices and may be boiled or fried [42]

Protection of this intangible cultural heritage is specifically a guarding against globalization and social transformation processes and is comparable to the intolerance of threats to natural resources and of the disappearance and destruction of intangible cultural heritage in the face of the homogenizing effect of globalization (UNESCO, 2008).

In light of this issue, the preservation and protection of the heritage of traditional Riau Malay food are beginning to be taken more seriously. In general, traditional Riau Malay food is a topic of debate, owing to its tracing its general historical roots back to other Asian countries such as Malaysia, Singapore, and India [47]. This debate consists of each country seeking to validate its claim to the traditional food as part of its own identity [48].

Food carries the dynamic potential for development in the world of multiculturalism [49]. However, despite this dynamic potential, there remains a strong demand among consumers for the faithfulness of the traditional food to its authenticity identity, in appreciation for its value as a cultural heritage [50]. Food as a cultural heritage and sign of ethnic identity has become a very important topic for discussion as the era of globalization makes it very possible for the commodification of traditional food to obliterate its authenticity values. The threat toward the authenticity of traditional food has become an object of interest compelling many parties to give greater attention to the protection and preservation thereof [51].

The Riau Malay are one of the ethnic peoples of Indonesia, one piece of the multiethnic mosaic of Southeast Asia. Some ethnic similarities may be found in certain neighboring countries in Southeast Asia such as Malaysia, Singapore, and Brunei Darussalam, which also generally feature Malay ethnic groups. As for the traditional cuisine of Riau Malay, one may no doubt discern the influence of a variety of Malay cultures from throughout Southeast Asia, making it difficult to declare the authenticity of food [52], all the more in the current era when commodification is gaining ground as a global trend. This debate enters into a variety of realms, including those of academy, business, community, and individual [53]. In the case of Riau Malay, the countries of Indonesia and Malaysia are seen in the general context of similarity, despite differing in specifics. Both are ethnically Malay. This issue leads to debate especially in determining where true authenticity and identity lie. 
On the topic of cuisine, traditional Malay food generally emerged in the fifteenth century in the era of the Melaka Sultanate as the central trading power in the Malay archipelago, yet the authenticity of Malay cuisine is believed to pre-date the Melaka Sultanate, as its form is considered to have existed contemporaneously with the emergence of society at that time, not with the sultanate's rise to power. Malay cuisine is also found in Malaysia, Singapore, and Brunei Darussalam, which are known to be in the same Malay archipelago. Malay cuisine is halal in accordance with the dietary guidelines of Islam. Thus, its sources of proteins are selected from beef, chicken, water buffalo, and goats, and alcohol is absent, being forbidden in Malay cuisine. Each traditional Malay region has its own traditional cuisine. The primary common features are the rich flavor and generous use of spices. The Riau Malay in Indonesia tends to employ a spicy-sour flavor in a liberal combination of spices, with a relatively low level of coconut milk content for sweets and snacks. It is known that other Malay cuisines do not employ as much use of spices as is employed by the Riau Malay.

The majority of traditional Riau Malay foods with which we are familiar at this point are generally known as foods that have been passed down from previous generations. However, among these foods are those that are undergoing commodification, change in production for the purpose of commercialization in response to the changing tastes of the modern market. For example, the kue bangkit ("rising pastry") authentically featured only one flavor, but is now available in a variety of flavors, including chocolate, durian, green tea, lime, and others. Kue bangkit has been the preferred pastry of the kingdom of Siak for over five centuries, regularly consumed and served at ritual royal events and major religious celebrations. Eventually, the pastry came to be known among commoners as a group of women in a social circle began producing it for the general market as a trademark traditional Riau Malay food.

The same phenomenon took place with the bolu kemojo ("kemojo sponge cake"). Authentically, the bolu kemojo was cooked in a traditional manner, baked over coals, and available in only one flavor, that of pandan leaves, with sugar serving as a preservative. At present, bolu kemojo may be found in a variety of flavors such as chocolate flavors, durian flavors, corn flavors, and is no longer cooked over coals, but in an oven for ease of large-scale production. In a few cases, this change may be seen as instances of commodification, triggered by the development of consumer interests in this global market era. Business actors in the traditional food industry see a great business opportunity in this area, if they are able to successfully commercialize by enacting commodification in accordance with market interests.
Although commercialization carries the potential for a loss of authenticity [29], it remains important enough to require consideration and the search for a solution.

In certain other areas, however, the authenticity of traditional Riau Malay foods has been preserved, such as the traditional method of preparing certain dishes, perpetuating the cooking methods passed down from previous generations, not involving the use of modern tools or technology, even considering them as something to be avoided in the cooking process. Such is the case with the asidah pastry, which is believed to be ruined by any involvement of modern machinery.

The commodification of certain traditional Riau Malay foods is known to have involved mobility of change in the direction of commercialization and modernization, while retaining the authenticity identity and historic values contained therein. Yet amid the change, it is consequentially becoming more and more difficult to discern the authenticity values. This is what must be continually held in consideration, although the reality is that food is an item the authenticity of which is difficult to honestly describe [54].

Other than Malaysia, Singapore also constitutes a multiethnic nation, the cuisine of which is believed to be of the same family as that of Malaysia [44, 52, 53], as well as Indonesia. Take, for instance, the popular controversy of nasi lemak, the origin of which is often debated, carrying iconicity in each country. Each country lays forth its own argument claiming precedence and authenticity of the dish as their own. Such a debate will be difficult to resolve, as the development of cuisine in a multiethnic environment is dynamic in nature [49], with variety in the ingredients used, the technology involved, and the ongoing evolution of culinary knowledge each contributing to the difficulty of uncovering the authenticity form [54].

\section{The sustainability of traditional Riau Malay food}

The sustainability of a business venture requires selfawareness of one's place in a complex system with the potential to create economic, social, and environmental wealth [55]. It is no different in the food industry; the business venture must be able to create, distribute, and retain value for all stakeholders [55-57]. A production company no longer views itself as separated from the system [55], but much join in common interests with partners and consumers to create a wide-reaching system of values [58-60].

A business's ability to compete depends largely upon its ability to simultaneously operate in multiple dimensions, those of cost, quality, exporting, handling, speed, innovation, and flexibility in adapting to a variety of demands [61-63].

In this discussion, the resources-based view (RBV) constitutes a useful theoretical framework, considering a 
diversity of resources to be essential in achieving excellence in sustainable competitiveness with the following characteristics: value, rarity, inimitable, and nonsubstitution [59, 64-66]. A business' resources are identified as valuable if an environment undergoes change; this analysis is based on the assessment of dynamic opportunities and threats. It should be understood that this phenomenon is in accordance with the RBV view of a business' resources [67].

In the context of the sustainability of traditional Riau Malay food, Riau's traditional Malay foods, business people said that the main challenge faced today was the main challenge being faced presently is the optimization of the potential of local resources, from the availability of ingredients, to local ability, knowledge, and performance. The ongoing debate over the origin of certain dishes with its various claims is another challenge that must be overcome if the traditional food of Riau Malay is to take on a clear identity distinct from alternatives. This is achievable if the business actors in the Riau Malay food industry are able to activate the potential of their diverse resources, set themselves apart from competitors, cultivate a unique set of values that distinguishes them from the competition, and maintain an immovable stance such as is irreplicable by those who would seek to copy the strategy [67]. Retaining key historical values will always produce a trademark quality. The current condition of traditional Riau Malay cuisine remains well-protected with regard to its authenticity, despite the various elements that have undergone commodification. We can state with certainty that this will not undermine its authenticity values.

The concept of resource-based study focuses on the formation of organizational ability, especially the realization of competitive business advantage, as a result of achieving a unique combination of resources and business assets, difficult to duplicate, replace, or find elsewhere. The opportunities and threats of globalization continue to elevate, pushing business actors to strengthen their resources and abilities and compensate for their weaknesses.

\section{Conclusion}

Traditional Riau Malay food carries a historical background carrying similarity to those of neighboring countries such as Malaysia, Singapore, and Brunei Darussalam. Nevertheless, each country and region boasts its own distinct flavor and culinary tradition and combination of seasonings, such that one may discern the authenticity of each region. Traditional Riau Malay food is currently being well-protected in terms of sustainable competitiveness in the global market era. Its trademark flavor is inseparable from the rich historic values that have been passed down in shared memories from generation to generation. These values will not be replaced easily, even by the process of commodification that eventually tends toward commercialization and modernization, which have the potential to effect the loss of the authenticity of this cuisine.

In spite of the challenges raised by modern culinary variety and trending flavors, the traditional cuisine of the Riau Malay retains its sustainable competitiveness in the global market. Its historic values, the memory of the past, and the culmination of authentic experience passed down through the generations lends it a unique and captivating strength translating into a sustainable position in the global market.

\section{Acknowledgements \\ Thank you for Mr. Asep Miftahuddin who has been helping the authors in the process of this article in grammatical and language issues. \\ Thank you for Mrs. Sri Bulan and Mrs. Martijah who has been contributing an important information about traditional Riau Malay food culture.}

\section{Authors' contributions}

AM carried out on the main ideas and writing of this article in research on Riau Malay foods. SJR carried out on the literature review, final review of the overall contents of the review article. BH participated carried out in research methods. TH participated carried out on the content of marketing and business aspects of Riau Malay food. All authors read and approved the final manuscript.

\section{Funding}

This study did not receive the support of certain costs from the funding agency in the public, commercial, or non-profit sector.

\section{Availability of data and materials}

We do not wish to share our data, for some confidential statement from some information which cannot be shared in public.

\section{Competing interests}

The authors declare that they have no competing interests.

Received: 27 December 2018 Accepted: 27 May 2019

Published online: 17 July 2019

\section{References}

1. Barker C. Cultural studies, theory and practice. London: Sage Publication; 2000.

2. Phillips L. Food and globalisation. Annu Rev Anthropol. 2006;35:35-57.

3. Watson, Caldwel. The cultural politics of food and eating: a reader. Malden: Blackwell Publishing; 2005.

4. Ritzer G. The McDonaldization of Society. London: Sage; 1995.

5. Jordana J. Traditional foods: challenges facing the European food industry. Food Res Int. 2000;33:147-52.

6. Pieniak Z, Verbeke W, Vanhonacker F, Guerrero L, Hersleth M. Association between traditional food consumption and motives for food choice in six European countries. Appetite. 2009;53(1):101-8.

7. Shepherd R. Commodification, culture and tourism. Tour Stud. 2002;2(2):183-201.

8. Cole S. Beyond authenticity and commodification. Ann Tour Res. 2007;34(4):943-60.

9. Guerrero L, et al. Perception of traditional food products in six European regions using free word association. Food Qual Prefer. 2009;21(2):225-33.

10. Maclean D, Andjelkovic M, Vetter T. Intangible cultural heritage and sustainable development, vol. 8; 2007.

11. Aykan B. The politics of intangible heritage and food fights in Western Asia. Int J Herit Stud. 2016;22(10):799-810.

12. Matta R. Valuing native eating: the modern roots of Peruvian food heritage; 2013.

13. Bessière J, et al. Patrimoine alimentaire et innovations Essai d'analyse typologique sur trois territoires de la Region Midi-Pyrenees. In: Proc. a Symp. Innov. Sustain. Dev. Agric. Food Montpellier Fr. 28 June to 1st July 2010; 2010. p. 1-12. 
14. Timothy DJ. Cultural heritage and tourism: an introduction aspects of tourism texts. Bristol, London: Channel View Publications; 2011.

15. Chambers S, Lobb A, Butler L, Harvey K, Bruce Traill W. Local, national and imported foods: a qualitative study. Appetite. 2007;49(1):208-13.

16. Di Giovine MA. The everyday as extraordinary: revitalization, religion, and the elevation of Cucina Casareccia to heritage cuisine in Pietrelcina, Italy. In: Edible identities: food as cultural heritage: Ashgate; 2014. https://www. academia.edu/12647867/The_Everyday_as_Extraordinary_Revitalization_ Religion_and_the_Elevation_of_Cucina_Casareccia_to_Heritage_Cuisine_in_ Pietrelcina_Italy.

17. Bourdieu P. Distinction: a social critique of the judgement of taste. Cambridge: Harvard University Press; 1984

18. Mintz SW, Du Bois CM. The anthropology of food and eating. Annu Rev Anthropol. 2002;31(1):99-119.

19. Lindquist CS, Gabaccia DR. We are what we eat: ethnic food and the making of Americans. Contemp Sociol. 1999;28(3):326.

20. Andersen EN. Everyone eat: understanding food and culture. 2nd ed. New York: New York University Press; 2014.

21. Kittler PG, Sucher KP, Nelms M. Food and culture. 6th ed. Boston: Cengage Learning; 2012.

22. Tarr A. Food and culture: from local relationality to global responsibility. J Dialogue Cult. 2016;3(1):52-62.

23. Moreiras A. Global fragments: a second latinamericanism. In: Jameson F, Miyosh M, editors. The cultures of globalization. Durham: Duke University Press; 2004.

24. Naisbitt J. Global Paradox. New York: Avon Book; 1995.

25. Giddens A. Runaway World: Bagaimana Globalisasi Merombak Kehidupan Kita. Jakarta: Gramedia; 2001.

26. Kwon DY. Ethnic foods and globalization. J Ethn Foods. 2017;4(1):1-2.

27. Platania M, Privitera D. Typical products and consumer preferences: the 'soppressata' case. Br Food J. 2006;108(5):385-95.

28. Wycherley A, McCarthy M, Cowan C. Speciality food orientation of food related lifestyle (FRL) segments in Great Britain. Food Qual Prefer. 2008;19(5):498-510.

29. Cheung $\mathrm{SCH}$. From foodways to intangible heritage: a case study of Chinese culinary resource, retail and recipe in Hong Kong. Int J Herit Stud. 2013;19(4):353-64

30. UNESCO. World Heritage Information Kit. France: UNESCO World Heritage Center Retrieved from http://whc.unesco.org; 2003.

31. Horng J-S, Tsai CT. Government websites for promoting East Asian culinary tourism: a crosss-national analysis. Tour Manag. 2010;31(1):74-85.

32. Lin Y-C, Pearson TE, Cai LA. Food as a form of destination identity: a tourism destination brand perspective. Tour Hosp Res. 2011;11(1):30-48.

33. McDonald $\mathrm{H}$. Understanding the antecedents to public interest and engagement with heritage. Eur J Mark. 2011;45(5):780-804.

34. Vanhonacker F, Verbeke W, Guerrero L, Claret A, Contel M, Scalvedi L, Hersleth M. How European consumers define the concept of traditional food: evidence from a survey in six countries. Agribusiness. 2010;26(4):45376. https://doi.org/10.1002/agr.20241.

35. Creswell J. Research design qualitative, quantitative, and mixed methods approaches. 3rd ed. Thousand Oaks: Sage; 2009.

36. Miles MB, Huberman M. Qualitative data analysis - new method. Jakarta: UIP; 1992.

37. Liu C, Cai X, Zhu H. Eating out ethically: an analysis of the influence of ethical food consumption in a vegetarian restaurant in Guangzhou, China. Geogr Rev. 2015;105(4):551-65.

38. Wang YL. Study on sustainable development of Qinhuai culinary culture. Jiangsu Condiment Subsid Food. 2013;135:42-4

39. Rianti A, Novenia AE, Christopher A, Lestari D, Parassih EK. Ketupat as traditional food of Indonesian culture. J Ethn Foods. 2018;5(1):4-9.

40. Asam Pedas Ikan ("Spicy-sour Fish"). https://static.limakaki.com/2018/10/ Cara-Buat-Gulai-Ikan-Patin-Khas-Riau.jpg.

41. Salai Fish. https://img.okeinfo.net/content/2017/07/14/298/1736390/punyaikan-selais-riau-di-rumah-masak-sambal-balado-yang-pedasnya-nendangyuk-naQStCIONJ.jpg.

42. Sagu Noodles. https://www.riau.go.id/home/bankdataimage/mie-sagukuliner-wajib-dicicipi-bila-datang-ke.jpg. Accessed 6 June 2018.

43. Effendy T. Tunjuk Ajar Melayu. Pekanbaru: Tenas Effendy Foundation dan Dinas Kebudayaan dan Pariwisata Provinsi Riau; 2013

44. Kwon DY. What is ethnic food? J Ethn. 2015;2:6181

45. Abarca ME. Authentic or not, it's original. Food Foodways. 2004;12:1-25.

46. Ting H, Rebecca S, Nastassia A. Consumption intention toward ethnic food : determinants of Dayak food choice by Malaysians. J Ethn Foods. 2017;4(1):21-7.
47. Raji MNA, Ab Karim S, Ishak FAC, Arshad MM. Past and present practices of the Malay food heritage and culture in Malaysia. J Ethn Foods. 2017;4(4):221-31.

48. Ramli AM, Zahari MSM, Halim NA, Aris MHM. The knowledge of food heritage Identithy in Klang Valley, Malaysia. Procedia Soc Behav Sci. 2016; 222:518-27.

49. Scarpato R, Daniele R. New global cuisine: tourism, authenticity and sense of place in postmodern gastronomy. In: Hall CM, Sharpley $L$, Mitchell R, Maconis N, Cambourne B, editors. Food tourism around the world: development, management and markets. Oxford: ButterworthHeinemann; 2003.

50. Gilmore JH, Pine JB. What consumers really want: authenticity. Boston: Harvard Business School Press; 2007.

51. Stiles K, Altiok Ö, Bell MM. The ghosts of taste: food and the cultural politics of authenticity. Agric Hum Values. 2011;28(2):225-36.

52. Reisinger $Y$, Steiner $C J$. Reconceptualizing object authenticity. Ann Tour Res. 2006;33(1):65-86.

53. Beer S. Authenticity and food experience-commercial and academic perspectives*. J Foodserv. 2008;19(3):153-63.

54. Cook I, Crang P, Thorpe M. Regions to be cheerful: culinary authenticity and its geographies. In: Cook I, Crouch D, Naylor S, Ryan JR, editors. Cultural turns/ geographical turns. Harlow: Prentice-Hall; 2000.

55. Lee KJ, Casalegno F. An explorative study for business models for sustainability; 2010. p. 423-32.

56. Hutton W. The food of Malaysia: authentic recipes from the crossroads of Asia. Singapore: Periplus; 2000.

57. Jalis, Othman. Western tourists perception of Malaysian gastronomic products. Asian Soc Sci. 2009;5:25-36

58. Zeng G, Go F, de Vries HJ. Paradox of authenticity vs. standardization: Expansion strategies of restaurant groups in China. Int J Hosp Manag. 31: 1090-100.

59. Stubbs W, Cocklin C. Conceptualizing a 'sustainability business model. Organ Environ. 2008;21(2):103-27.

60. Carpinetti LCR, Buosi T, Gerólamo MC. Quality management and improvement. Bus Process Manag J. 2003;9(4):543-54.

61. Osterwalder A, Pigneur Y, Tucci CL. Clarifying business models: origins, present, and future of the concept. Commun Assoc Inf Syst. 2005;16:2-25.

62. Osterwalder A, Pigneur $Y$. Business model generation: a handbook for visionaries, game changers and challengers. Hoboken: Wiley; 2010.

63. Zott, Massa $L$, The business model: recent developments and future research Raphael Amit, no. February 2011, 2015.

64. Carpinetti LC r, Buosi T, Gerólamo MC. Quality management and improvement: a framework and a business-process reference model. Bus Process Manag J. 2003;9(4):543-54.

65. Barney J. Barney 1991.pdf. J Manag. 1991;17(1):99-120.

66. Barney JB. Gaining and sustaining competitive advantage. 3ed ed. Upper Saddle River: Pearson International Education Inc., Publishing as Prentice-Hall; 2007.

67. Barney J. Firm resources and sustained competitive advantage. J Manag 1991;17(1):99-120.

\section{Publisher's Note}

Springer Nature remains neutral with regard to jurisdictional claims in published maps and institutional affiliations.

Ready to submit your research? Choose BMC and benefit from:

- fast, convenient online submission

- thorough peer review by experienced researchers in your field

- rapid publication on acceptance

- support for research data, including large and complex data types

- gold Open Access which fosters wider collaboration and increased citations

- maximum visibility for your research: over $100 \mathrm{M}$ website views per year

At BMC, research is always in progress.

Learn more biomedcentral.com/submission 